\title{
COVID-19 Pandemisinde Üçüncü Basamak Bir Hastane Deneyimi
}

\section{A Tertiary Care Hospital Experience During the COVID-19 Pandemic}

\begin{abstract}
Mine FiLiZ'(IID), Gülden YILMAZ'(ID), Gonca FiDAN'(IID), Sümeyye KÖȘGER'(IID), Ekin KADIOG̃LU²(ID), Ümit SAVAȘCl'(ID), Yavuz ÇEKLi'(IID), Nesrin ÖCAL ${ }^{3}(\mathrm{IID})$, Deniz DOG̃AN $^{3}$ (IID), Yakup ARSLAN ${ }^{3}$ (ID),

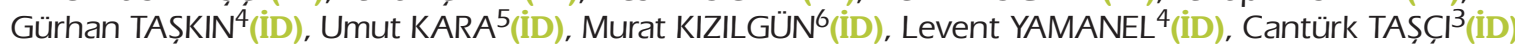

\footnotetext{
${ }^{1}$ Sag̃ılı Bilimleri Üniversitesi, Gülhane Eg̃itim ve Araștırma Hastanesi, İnfeksiyon Hastalıkları ve Klinik Mikrobiyoloji Klinig̃i, Ankara, Türkiye

2 Sag̃ılı Bilimleri Üniversitesi, Gülhane Eg̃itim ve Araștırma Hastanesi, iç Hastalıkları Klinig̃i, Ankara, Türkiye

${ }^{3}$ Sag̃lık Bilimleri Üniversitesi, Gülhane Eg̃itim ve Araștırma Hastanesi, Göğüs Hastalıkları Klinig̃i, Ankara, Türkiye

${ }^{4}$ Sag̃lık Bilimleri Üniversitesi, Gülhane Eg̃itim ve Araștırma Hastanesi, Yog̃un Bakım Klinig̃i, Ankara, Türkiye

${ }^{5}$ Sag̃lık Bilimleri Üniversitesi, Gülhane Eg̃itim ve Araștırma Hastanesi, Anesteziyoloji ve Reanimasyon Klinig̃i, Ankara, Türkiye

${ }^{6}$ Sag̃lık Bilimleri Üniversitesi, Gülhane Eg̃itim ve Araștırma Hastanesi, Tıbbi Biyokimya Klinig̃i, Ankara, Türkiye
}

Makale atıfı: Filiz M, Yılmaz G, Fidan G, Köşger S, Kadıoğlu E, Savaşçı Ü ve ark. COVID-19 pandemisinde üçüncü basamak bir hastane deneyimi. FLORA 2021;26(2):257-66.

\section{ÖZ}

Giriş: COVID-19 hastalarında hastalığın ciddiyetinin erkenden tespiti hem hastalık prognozu hem de sağlık kurumlarının etkin kullanımı açııından önem taşımaktadır. Hastaların erken tanınması ve agresif destek tedavisinin sağlanması hasta yönetiminin temel noktasıdır. Bu nedenle bu çalışmada; COVID-19 tanısıla yatırılarak izlenen hastaların demografik, klinik, laboratuvar ve radyolojik bulguları değerlendirilmiş ve ciddi seyirde yol gösterebilecek risk faktörlerinin belirlenmesi amaçlanmıştır.

Materyal ve Metod: COVID-19 tanısılla yatırılarak izlenen toplam 579 olgu retrospektif olarak değerlendirilmiştir. Polimeraz zincir reaksiyonu (PCR) pozitifliği ve/veya tipik klinik, laboratuvar ve radyolojik bulguları ile COVID-19 tanısı konulup tedavi alan vakalar çalısmaya alınmıştır. Çalışma popülasyonu; Dünya Sağlık Örgütü (DSÖ) COVID-19 hastalık şiddeti sınıflanmasına göre gruplara ayrılmıştır. Bu grupların demografik, klinik, laboratuvar ve radyolojik verileri karşılaştırılarak ciddi seyirli hastalık ve mortalite açısından anlamlı risk faktörleri belirlenmeye çalışılmıştır.

Bulgular: Toplam 579 olgunun ortalama yaşı $54 \pm 18.25$ idi ve 321 (\%55.4)'i erkekti. Hastaların 131 (\%22.6)'inde ciddi seyirli hastalık saptanmıştır ve mortalite oranı \%8.29 idi. Hastalarda en sık saptanan komorbiditeler; sırasıyla hipertansiyon (\%31.8), diyabetes mellitus (\%18.5) ve koroner arter hastalığı (\%17.8) olarak bulunmuştur. Hastaneye başvuru anında en sık görülen semptomlar; öksürük (\%40.7), ateş $\left(\geq 38^{\circ} \mathrm{C} ; \% 33.6\right)$ ve nefes darlığı (\%26.3) idi. Yaş, koroner arter hastalığı ve nefes darlığı varlığı, nötrofil sayısı, üre, CRP, ferritin, Pro-BNP, fibrinojen, IL-6 değerlerinin ciddi seyirli hastalık açısından prediktif göstergeler olduğu saptanmıştır. Bu değişkenler arasında; yaş, nefes darlığı varlığı, üre, ferritin ve Pro-BNP'nin bağımsız prediktif değişkenler olduğu ve hesaplanabilen değişkenler için eşik değerler ("cut-off point"); yaş (59.5), üre (33.5 mg/dL), ferritin (50.8 $\mathrm{gg} / \mathrm{L})$ ve Pro-BNP (881 pg/mL) olarak bulunmuştur.

Sonuç: COVID-19 hastalığında ciddi hastalık seyri açısından bazı prediktif faktörler olduğu görülmüştür. Bu faktörlerin dikkate alınarak riskin öngörülmesi; hekim ve diğer sağlık çalışanlarına yakından takip edilmesi gereken hasta grubunu saptamak, erken ve uygun tedavi ile bu hastalardaki mortalite oranlarının düşürülmesi ve sürecin uygun yönetimi açısından yol gösterici olacaktır.

Anahtar Kelimeler: COVID-19; SARS-CoV-2; Pandemi

Geliș Tarihi/Received: 11/02/2021 - Kabul Ediliș Tarihi/Accepted: 26/03/2021

${ }^{\circledR}$ Telif Haklı 2021 Flora. Makale metnine www.floradergisi.org web adresinden ulașılabilir. 


\title{
ABSTRACT \\ A Tertiary Care Hospital Experience During the COVID-19 Pandemic
}

\author{
Mine FiLiZ1', Gülden YILMAZ1', Gonca FiDAN', Sümeyye KÖȘGER', Ekin KADIOG̃LU², Ümit SAVAȘCI', \\ Yavuz ÇEKLi', Nesrin ÖCAL ${ }^{3}$, Deniz DOG̃AN ${ }^{3}$, Yakup ARSLAN ${ }^{3}$, Gürhan TAȘKIN ${ }^{4}$, Umut KARA ${ }^{5}$, \\ Murat KIZILGÜN ${ }^{6}$, Levent YAMANEL ${ }^{4}$, Cantürk TAȘÇI
}

\footnotetext{
${ }^{1}$ Clinic of Infectious Diseases and Clinical Microbiology, University of Health Sciences, Gülhane Training and Research Hospital, Ankara, Turkey

${ }^{2}$ Clinic of Internal Diseases, University of Health Sciences, Gülhane Training and Research Hospital, Ankara, Turkey

${ }^{3}$ Clinic of Chest Diseases, University of Health Sciences, Gülhane Training and Research Hospital, Ankara, Turkey

${ }^{4}$ Clinic of Intensive Care, University of Health Sciences, Gülhane Training and Research Hospital, Ankara, Turkey

${ }^{5}$ Clinic of Anesthesiology and Reanimation, University of Health Sciences, Gülhane Training and Research Hospital, Ankara, Turkey

${ }^{6}$ Clinic of Medical Biochemistry, University of Health Sciences, Gülhane Training and Research Hospital, Ankara, Turkey
}

Introduction: Early detection of the severity of COVID-19 disease is important for patient prognosis and effective use of hospital capacity. Early detection of critical patients and providing supportive treatment is the main goal of disease management. In this study, we evaluated demographic, clinical, laboratory and radiological findings in COVID-19 patients and aimed to find risk factors associated with poor prognosis.

Materials and Methods: A total of 579 cases hospitalized with the diagnosis of COVID-19 were evaluated retrospectively. The diagnosis of COVID-19 was confirmed by polymerase chain reaction (PCR) positivity or typical clinical, laboratory and radiological findings. The study population was divided into groups according to the World Health Organization (WHO) COVID-19 disease severity classification. Significant risk factors associated with severe disease and mortality were investigated by comparing the demographic, clinical, laboratory and radiological data of these groups.

Results: Mean age of the 579 cases was $54 \pm 18.25$, and 321 of them (55.4\%) were male. Severe disease was detected in 131 (22.6\%) patients and mortality rate was \%8.29. The most common comorbidities were hypertension (31.8\%), diabetes mellitus (18.5\%) and coronary artery disease (17.8\%), respectively. The most common symptoms at the time of admission to the hospital were cough $(40.7 \%)$, fever $\left(38^{\circ} \mathrm{C} ; 33.6 \%\right)$ and shortness of breath $(26.3 \%)$. Age, coronary artery disease and shortness of breath, neutrophil count, urea, $C R P$, ferritin, Pro-BNP, fibronogen, IL-6 values were found to be predictive variables for severe disease. Age, presence of shortness of breath, urea, ferritin and Pro-BNP values were found to be independent predictive variables for severe disease, and the cut-off points were calculated for these variables (age 59.5, urea $33.5 \mathrm{mg} / \mathrm{dL}$, ferritin $50.8 \mu \mathrm{g} / \mathrm{L}$ and Pro-BNP $881 \mathrm{pg} / \mathrm{mL}$ ).

Conclusion: Some predictive factors were demonstrated to detect severe disease in COVID-19 patients. It is important to predict poor prognosis based on these factors. It provides early detection of critical patients and it will be a guide for reducing mortality rates in these patients with effective treatment.

Key Words: COVID-19; SARS-CoV-2; Pandemic

\section{GiRiș}

Koronavirüsler, Coronaviridae familyasındaki Orthocoronavirinae alt familyasından tek zincirli, pozitif polariteli, zarflı RNA virüsleri olup önemli insan ve hayvan patojenleridir. 2019 yilının son günlerinde Cin Halk Cumhuriyeti Wuhan sehrindeki Huanan Deniz Ürünleri Pazarı'nda görülen bazı pnömoni olguları yeni bir koronavirüs salgını ile ilișkilendirilmiștir ${ }^{[1]}$. Bu yeni koronavirüs siddetli akut solunum sendromu koronavirüs-2 (SARSCoV-2) olarak adlandırılmıș ve virüsün yol açtığı klinik hastalığa da Koronavirüs hastalığı 2019 (COVID-19) adı verilmiștir. COVID-19 hızla bir- çok ülkeye yayılmıs ve 11 Mart 2020 tarihinde Dünya Sağllk Örgütü (DSÖ) tarafından pandemi (küresel salgın) olarak kabul edilmiștir ${ }^{[2]}$. Tüm dünyada ilk on ay içinde COVID-19 tanısı alan 97 milyonun üzerinde olgu ve 2 milyonun üzerinde ölüm bildirilmistirr ${ }^{[3]}$. Ülkemizde ise sayısı 2.5 milyona yaklașan olgu ve 24000 'in üzerinde ölüm görülmüștür ${ }^{[4]}$.

SARS-CoV-2 esas olarak damlacık yoluyla bulașmaktadır. Hastalığın bulașması, öncelikle infekte olmus kișilerin solunum sekresyonlarıyla doğrudan temasla veya bu kișilerin öksürmesi, hapșırması yoluyla ortaya saçtıkları solunum damlacıklarına 
diğer kișilerin elleriyle temas etmesi ve sonrasında ellerini ağız, burun veya göz mukozasına götürmesi ile de olabilmektedir ${ }^{[5]}$. Ates, öksürük, nefes darlığı gibi semptomlar COVID-19'un en sık görülen belirtileri olmasına rağmen; COVID-19'u diğer viral solunum yolu infeksiyonlarından güvenilir bir sekilde ayırabilen spesifik bir klinik özellik yoktur.

COVID-19'un klinik spektrumu, asemptomatik infeksiyondan yașamı tehdit eden siddetli akut solunum sıkıntısı sendromu (ARDS) ve ölüme kadar uzanmaktadır ${ }^{[6,7]}$. Hastanın evde mi yoksa hastanede mi takip edileceği, hastanede takip edilecekse gelișmiș bir merkeze nakil ihtiyacı olup olmadığına karar verilmesi hem hastalık prognozu hem de sağlık kurumlarının etkin kullanımı açısından önem tașımaktadır. Özellikle ciddi seyir gösterebilecek hastaların erken tanınması ve agresif destek tedavisinin sağlanması hasta yönetiminin temel noktasıdır. Bu nedenlerle bu çalıșmada; COVID-19 tanısıyla yatırılarak izlenen hastaların demografik, klinik, laboratuvar ve radyolojik bulguları değerlendirilmiș ve ciddi seyirde yol gösterebilecek risk faktörlerinin belirlenmesi amaclanmıstır.

\section{MATERYAL ve METOD}

Coronavirüs hastalığı tanısı ile 18 Mart-1 Haziran 2020 tarihleri arasında Gülhane Eğitim ve Araștırma Hastanesi'nde yatarak tedavi edilen tüm hastalar değerlendirmeye alınmıștır. Bu hastalar arasından; 18 yaș ve üzerinde olup polimeraz zincir reaksiyonu (PCR) pozitifliği ve/veya tipik klinik, laboratuvar ve radyolojik bulguları ile COVID-19 tanısı konulup tedavi alan vakalar calıșmaya alınmıștır. PCR negatif ve/veya klinik-radyoloji negatif olan hastalar ile 18 yas altı hastalar çalıșma dıșında bırakılmıștır. Bu olguların dosya verileri retrospektif olarak taranmıstır.

Calıșma popülasyonu; DSÖ COVID-19 hastalık șiddeti sinıflanmasına göre gruplara ayrılmıștır ${ }^{[8]}$. Pnömoni veya hipoksi kanitı olmayan hastalar hafif derecede; pnömoni belirti ve semptomları olan, ancak siddetli pnömoni belirtisi olmayan hastalar ise orta derecede kabul edilmiștir. Pnömoni belirti ve semptomları olan hastalarda, solunum hizı $>30 /$ dk olması veya siddetli solunum sıkıntısı olması veya oda havasındaki $\mathrm{SpO}_{2}<\% 90$ olmas1 siddetli; mekanik ventilasyon gerektiren ARDS veya diğer solunum yetmezliği veya septik sok ve/veya yoğun bakım ünitesi (YBÜ) takibi gerekti- ren organ yetmezliği olan hastalar ise kritik olarak kabul edilmistir. Hafif ve orta derecede klinikle takip edilen hastalar ciddi seyirli olmayan hastalı; siddetli ve kritik klinikle takip edilip taburcu olan ya da ölen hastalar ise ciddi seyirli hastalık olarak gruplandırılmıstır. Bu grupların demografik (yas, cinsiyet, vücut kitle indeksi klinik (ateș, öksürük, nefes darlığı laboratuvar (lenfosit, C-reaktif protein, D-dimer ve radyolojik (PA akciğer grafisi, yüksek rezolüsyonlu bilgisayarlı tomografi) verileri karșılaștırılarak ciddi seyirli hastalık ve fatalite açısından anlamlı risk faktörleri belirlenmeye calıșılmıștır.

Tek değișkenli karșlaștırmalarda; sürekli değișkenlerin normal dağılıp dağılmadığı Shapiro Wilk testi, varyansların homojenliği ise Levene testi ile değerlendirilmiștir. Veriler; ortalama \pm standart sapma veya medyan (minimum-maksimum) değerleri ile özetlenmiștir. Parametrik varsayımlar sağlanmadığında, sayısal bir değișken bakımından bağımsız iki grubun karșılaștırılmasında Mann-Whitney U testi; parametrik varsayımlar sağlandığında ise iki ortalama arasındaki farkın önemlilik testi (Student's t testi) uygulanmıștır. Kategorik değișkenlerde veriler yüzdeliklerle özetlenmiștir. Kategorik bir değișken bakımından bağımsız iki grubun karșılaștırılmasında varsayımlar karşılamaları değerlendirilerek Ki-kare testi veya Fisher Exact testi uygulanmıstır.

Cok değiskenli karșılaștırmalarda ise; Least Absolute Shrinkage And Selection Operator (LAS$\mathrm{SO})$ regresyon modeli kullanılarak hastalığın kötü seyretmesinde prognostik faktörlerin seçimi yapılmıș ve prognostik faktörlerin cok değiskenli analizi için logistik regresyon modeli kullanılmıștır. Logistik regresyon sonucu anlamlı bulunan sürekli değișkenler için eșik değer belirlenebilmesi için ROC analizi yapilıp min-max kuralına göre esik değerler belirlenmiștir.

Hesaplamalarda birinci tip hata oranı alfa 0.05 kabul edilmis, istatistiksel analizler R 3.5.0 (R Core Team, 2018) yazılımı kullanılarak yapılmı̣ olup tablolar Microsoft Excel ile olușturulmuștur.

\section{BULGULAR}

$\mathrm{Bu}$ calıșmaya hastanemizde yatan 579 COVID-19 hastası dahil edilmistir. Hastaların ortalama yașı $54 \pm 18.2$ idi ve 321 (\%55.4)'i erkekti. Hastaların 131'inde (\%22.6) ciddi seyirli hastallk 
saptand 1 ve fatalite oranı $\% 8.3$ idi. Hastalarda saptanan en s1k komorbiditeler hipertansiyon (HT) (\%31.8), ardindan diyabetes mellitus (DM) (\%18.5) ve koroner arter hastalığıdır (KAH) (\%17.8).

Hastaneye bașuru anında en sı görülen semptomlar; öksürük (\%40.7), ates $\left(\geq 38^{\circ} \mathrm{C} ; \% 33.6\right)$ ve nefes darlığı (\%26.3) idi. Halsizlik (\%15.8), bulantı/kusma (\%6.3), ishal (\%3.3) ve koku/tat kayb1 (\%3.1) gibi ekstra pulmoner semptomlar da kaydedilmiștir. Hastaların ortalama semptom süresi ise $2.8 \pm 3.8$ gündür.

Hastalarının sosyodemografik özellikleri, komorbiditeleri ve klinik bulgulari; ciddi seyirli olmayan ve ciddi seyirli hastalık açısından gruplara ayrılarak Tablo 1'de özetlenmiștir.
Ciddi seyir gösteren hastaların hastaneye bașuru anındaki ilk değerlendirmelerinde; oksijen saturasyonları düsüik, nabız sayıları ve vücut sıcaklıkları ciddi seyirli olmayanlara göre daha yüksek saptanmiștır (Tablo 2).

Inflamatuvar parametreler arasında; ortalama C-reaktif protein (CRP) değeri $39.2 \pm 60.9 \mathrm{mg} / \mathrm{L}$, ortalama nötrofil sayısı $4637.4 \pm 3518.6 / \mu \mathrm{L}$ ve ortalama lenfosit sayisı $1524.1 \pm 1099.9 / \mu \mathrm{L}$ hesaplanmıștır (Tablo 2). Bașvuru anında yüksek rezolüsyonlu bilgisayarlı tomografi (HRCT) ile değerlendirme yapilan 552 hastanın 250 (\%45.3)'sinde COVID-19 hastalığı için tipik tutulumla uyumlu olarak bilateral buzlu cam opasitesi saptanmıștır, 114 (\%20.6) hastanın HRCT görüntulerinde ise herhangi bir tutulum saptanmamıștır (Tablo 2).

\begin{tabular}{|c|c|c|c|c|}
\hline & $\begin{array}{l}\text { Ciddi seyirli olmayan } \\
\text { hastalık ( } n=448 \text { hasta) }\end{array}$ & $\begin{array}{l}\text { Ciddi seyirli hastalık } \\
\quad(n=131 \text { hasta })\end{array}$ & $\begin{array}{c}\text { Toplam } \\
(\mathrm{n}=579 \text { hasta })\end{array}$ & $p$ \\
\hline Yaş (mean \pm SD) & $50.1( \pm 16.9)$ & $67.4( \pm 16.2)$ & $54.0( \pm 18.2)$ & $<0.001$ \\
\hline Cinsiyet $(n, \%)$ & & & & $>0.999$ \\
\hline Kadın & $200(\% 44.6)$ & $58(\% 44.2)$ & $258(\% 44.5)$ & \\
\hline Erkek & $248(\% 55.3)$ & $73(\% 55.7)$ & $321(\% 55.4)$ & \\
\hline \multicolumn{5}{|l|}{ Komorbidite (n,\%) } \\
\hline Diyabetes mellitus & $66(\% 14.7)$ & $41(\% 31.3)$ & $107(\% 18.4)$ & $<0.001$ \\
\hline Hipertansiyon & $117(\% 26.1)$ & $67(\% 51.1)$ & $184(\% 31.7)$ & $<0.001$ \\
\hline Hiperlipidemi & $41(\% 9.1)$ & $13(\% 9.9)$ & $54(\% 9.3)$ & 0.923 \\
\hline Koroner arter hastalığı & $52(\% 11.6)$ & $51(\% 38.9)$ & $103(\% 17.7)$ & $<0.001$ \\
\hline Kronik böbrek hastalığı & $11(\% 2.4)$ & $12(\% 9.1)$ & $23(\% 3.9)$ & 0.001 \\
\hline Kronik böbrek yetmezliği & $0(\% 0.0)$ & $4(\% 3.0)$ & $4(\% 0.6)$ & 0.002 \\
\hline Akut böbrek yetmezliği & $4(\% 0.8)$ & $13(\% 9.9)$ & $17(\% 2.9)$ & $<0.001$ \\
\hline $\mathrm{KOAH} /$ astım & $43(\% 9.6)$ & $33(\% 25.1)$ & $76(\% 13.1)$ & $<0.001$ \\
\hline Kronik karaciğer hastalığı & $4(\% 0.8)$ & $0(\% 0.0)$ & $4(\% 0.6)$ & 0.627 \\
\hline Kanser öyküsü & $14(\% 3.1)$ & $18(\% 13.7)$ & $32(\% 5.5)$ & $<0.001$ \\
\hline \multicolumn{5}{|l|}{ Klinik özellikler (n,\%) } \\
\hline Ateş & $141(\% 31.6)$ & $52(\% 40)$ & $193(\% 33.5)$ & 0.097 \\
\hline Öksürük & $174(\% 39.1)$ & $60(\% 46.1)$ & $234(\% 40.7)$ & 0.181 \\
\hline Nefes darlığı & 80 (\%17.9) & $71(\% 54.6)$ & $151(\% 26.2)$ & $<0.001$ \\
\hline Koku/tat kaybı & $17(\% 3.8)$ & $1(\% 0.7)$ & $18(\% 3.1)$ & 0.141 \\
\hline Halsizlik & 73 (\%16.4) & $18(\% 13.9)$ & 91 (\%15.8) & 0.593 \\
\hline İshal & $16(\% 3.6)$ & $3(\% 2.3)$ & $19(\% 3.3)$ & 0.657 \\
\hline Bulantı/kusma & $26(\% 5.8)$ & $10(\% 7.7)$ & $36(\% 6.2)$ & 0.561 \\
\hline $\begin{array}{l}\text { Başvuru anındaki semptom süresi } \\
(n=518 \text { hasta) (mean } \pm \text { SD) }\end{array}$ & $2.61( \pm 3.6)$ & $3.58( \pm 4.0)$ & $2.82( \pm 3.7)$ & $<0.001$ \\
\hline
\end{tabular}


Tablo 2. Hastaların başvuru anındaki vital bulguları, laboratuvar parametreleri ve görüntüleme bulguları

\begin{tabular}{|c|c|c|c|c|}
\hline & $\begin{array}{c}\text { Ciddi seyirli olmayan } \\
\text { hastalık ( } n=448 \text { hasta) }\end{array}$ & $\begin{array}{l}\text { Ciddi seyirli hastalık } \\
\quad(n=131 \text { hasta })\end{array}$ & $\begin{array}{c}\text { Toplam } \\
(\mathrm{n}=579 \text { Hasta) }\end{array}$ & $\mathbf{p}$ \\
\hline \multicolumn{5}{|l|}{ Vital parametreler (mean \pm SD) } \\
\hline Ateş ${ }^{\circ} \mathrm{C}(\mathrm{n}=477)$ & $36.9( \pm 0.8)$ & $37.2( \pm 0.9)$ & $36.9( \pm 0.8)$ & $<0.001$ \\
\hline Nabız atım/dk $(n=474)$ & $85.8( \pm 14.3)$ & $86.2( \pm 18.0)$ & $85.9( \pm 15.3)$ & 0.680 \\
\hline $\begin{array}{l}\text { Oksijen satürasyonu \% } \\
(n=470)\end{array}$ & $96.0( \pm 2.1)$ & $89.8( \pm 7.3)$ & $94.5( \pm 4.8)$ & $<0.001$ \\
\hline \multicolumn{5}{|l|}{$\begin{array}{l}\text { Laboratuvar parametreleri } \\
(\text { mean } \pm \text { SD) }\end{array}$} \\
\hline Lökosit sayısı, / $\mu \mathrm{L}$ & $6089.5( \pm 2739.5)$ & $9112.2( \pm 5551.5)$ & $6773.4( \pm 3786.6)$ & $<0.001$ \\
\hline Nötrofil sayısı, / $\mu \mathrm{L}$ & $3938.6( \pm 2487.3)$ & $7045.3( \pm 5137.9)$ & $4637.3( \pm 3518.6)$ & $<0.001$ \\
\hline Lenfosit sayısı, / $\mu \mathrm{L}$ & $1553.0( \pm 663.4)$ & $1425.1( \pm 1961.4)$ & $1524.0( \pm 1099.9)$ & $<0.001$ \\
\hline Hemoglobin, g/L & $13.5( \pm 1.8)$ & $12.6( \pm 2.1)$ & $13.3( \pm 1.9)$ & $<0.001$ \\
\hline Platelet sayısı, / $\mu \mathrm{L}$ & $232.9( \pm 90.5)$ & $222.0( \pm 98.2)$ & $230.4( \pm 92.4)$ & 0.082 \\
\hline Aspartat transaminaz (AST), U/L & $30.9( \pm 39.3)$ & $89.2( \pm 457.0)$ & $44.1( \pm 220.8)$ & $<0.001$ \\
\hline Alanin transaminaz (ALT), U/L & $30.6( \pm 39.6)$ & $70.9( \pm 429.8)$ & $39.7( \pm 207.5)$ & 0.527 \\
\hline Üre, mg/dL & $30.9( \pm 15.1)$ & $60.7( \pm 47.0)$ & $37.7( \pm 28.8)$ & $<0.001$ \\
\hline Kreatinin, md/dL & $0.9( \pm 0.2)$ & $1.2( \pm 0.8)$ & $1.0( \pm 0.5)$ & $<0.001$ \\
\hline Albümin, $g / L(n=479)$ & $3.8( \pm 0.4)$ & $3.2( \pm 0.6)$ & $3.7(0.5)$ & $<0.001$ \\
\hline $\begin{array}{l}\text { Laktat dehidrogenaz (LDH), U/L } \\
(n=565)\end{array}$ & $246.5(144.6)$ & 371.5 (244.) & $275.0( \pm 180.0)$ & $<0.001$ \\
\hline Sodyum, mEq/L & $138.5( \pm 6.2)$ & $137.3( \pm 6.5)$ & $138.2( \pm 6.3)$ & 0.002 \\
\hline Potasyum, $\mathrm{mmol} / \mathrm{L}$ & $4.1( \pm 0.4)$ & $4.1( \pm 0.7)$ & $4.1( \pm 0.5)$ & 0.727 \\
\hline Kalsiyum, mg/dL $(n=434)$ & $9.1( \pm 0.5)$ & $8.5( \pm 0.9)$ & $8.9( \pm 0.7)$ & $<0.001$ \\
\hline C-reaktif protein (CRP), mg/L & $27.0( \pm 45.8)$ & $80.5( \pm 83.6)$ & $39.2( \pm 60.9)$ & $<0.001$ \\
\hline $\begin{array}{l}\text { Eritrosit sedimentasyon hızı } \\
(E S R), m m / h(n=337)\end{array}$ & $41.1( \pm 27.8)$ & $54.7( \pm 28.7)$ & $44.5( \pm 28.6)$ & $<0.001$ \\
\hline Prokalsitonin, $\mathrm{pg} / \mathrm{mL}(\mathrm{n}=521)$ & $0.2( \pm 1.9)$ & $2.6( \pm 13.1)$ & $0.8( \pm 6.5)$ & $<0.001$ \\
\hline Ferritin, $\mu \mathrm{g} / \mathrm{L}(\mathrm{n}=294)$ & $181.5( \pm 212.5)$ & $388.6( \pm 438.0)$ & $257.6( \pm 329.5)$ & $<0.001$ \\
\hline D-dimer, mg/L $(n=516)$ & $0.7( \pm 1.1)$ & $4.3( \pm 12.5)$ & $1.5( \pm 6.3)$ & $<0.001$ \\
\hline Troponin, ng/L $(n=509)$ & $7.1( \pm 17.4)$ & $230.7( \pm 1012.6)$ & $60.7( \pm 503.6)$ & $<0.001$ \\
\hline $\begin{array}{l}\text { B-tipi natriüretik peptit (BNP), } \\
\mathrm{pg} / \mathrm{mL}(\mathrm{n}=113)\end{array}$ & $1158.8( \pm 3346.6)$ & $5867.0( \pm 7981.4)$ & $3408.7( \pm 6444.0)$ & $<0.001$ \\
\hline Fibrinojen, $g / L(n=334)$ & $370.2( \pm 152.9)$ & $432.9( \pm 168.4)$ & $389.9( \pm 160.3)$ & $<0.001$ \\
\hline $\begin{array}{l}\text { İnterlökin-6 (IL-6), pg/mL } \\
(\mathrm{n}=82)\end{array}$ & $58.7( \pm 105.7)$ & $301.4( \pm 479.5)$ & $209.7( \pm 400.1)$ & 0.001 \\
\hline HRCT bulguları $(n, \%)(n=552)$ & & & & $<0.001$ \\
\hline Bilateral buzlu cam opasitesi & $182(\% 42.8)$ & $68(\% 53.5)$ & $250(\% 45.2)$ & \\
\hline Tek taraflı buzlu cam opasitesi & $128(\% 30.1)$ & $48(\% 37.8)$ & $176(\% 31.8)$ & \\
\hline Konsolidasyon & $9(\% 2.1)$ & $3(\% 2.3)$ & $12(\% 2.1)$ & \\
\hline Tutulum yok & $106(\% 24.9)$ & $8(\% 6.3)$ & $114(\% 20.6)$ & \\
\hline
\end{tabular}




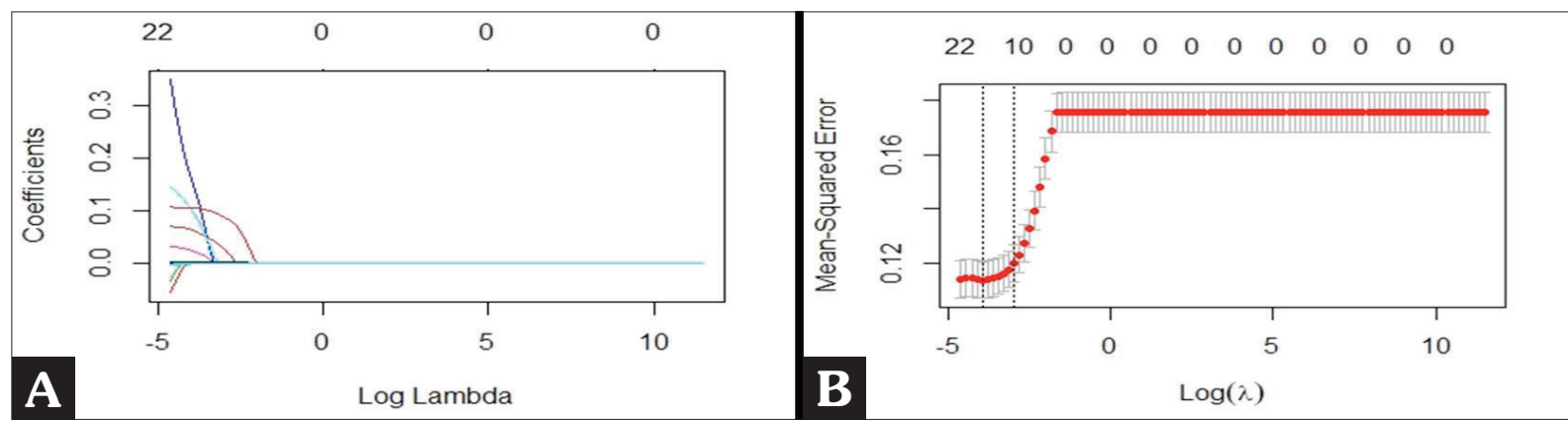

Şekil 1. LASSO regresyon modeli kullanılarak COVID-19 tanısı almada prognostik faktörlerin seçimi. A. COVID-19 tanısı faktörünün LASSO katsayı profilleri. B. LASSO regresyonu, optimal ayar parametresini $(\lambda)$ belirlemek için 10 kat çapraz doğrulama kullanmıştır.

Ciddi seyirli olmayan ve ciddi seyirli hastalığ1 saptamak açısından; vakaların tek değiskenli karșlaștırmalarında anlamlı fark bulunan ve hastaların durumunun kötüye gidișinde prediktif değisken olabileceği düșünülen toplam 34 değișken LASSO regresyonuna dahil edilmiștir. Bu değiskenler; yas, DM, HT, KAH, kronik böbrek hastalığı, kronik böbrek yetmezliği, akut böbrek yetmezliği, kronik obstruktif akciğer hastalığı/astım, kanser öyküsü, nefes darlığ1, bașvuru anındaki semptom süresi, ates, oksijen saturasyonu, lökosit sayısı, nötrofil say1s1, lenfosit sayıs1, hemoglobin, aspartat aminotransferaz, üre, kreatinin, albümin, laktat dehidrogenaz, sodyum, kalsiyum, CRP, eritrosit sedimentasyon hizı, prokalsitonin, ferritin, d-dimer, troponin, Pro-B tipi natriüretik peptit (Pro-BNP), fibrinojen, interlökin-6 (IL-6), HRCT bulgularıdır.

\begin{tabular}{|c|c|}
\hline Değişkenler & Ciddi seyirli hastalık \\
\hline Yaş & $1.032 *(1.014,1.051)$ \\
\hline $\mathrm{KAH}$ & $1.258(0.647,2.389)$ \\
\hline Nefes darlığı & $2.447^{*}(1.404,4.235)$ \\
\hline Nötrofil & $1.000(1.000,1.000)$ \\
\hline Üre & $1.017^{*}(1.006,1.031)$ \\
\hline CRP & $1.002(0.998,1.006)$ \\
\hline Ferritin & $1.002 *(1.001,1.003)$ \\
\hline Pro-BNP & $1.000 *(1.000,1.000)$ \\
\hline Fibronojen & $1.001(1.000,1.002)$ \\
\hline IL-6 & $1.003(1.000,1.007)$ \\
\hline
\end{tabular}

LASSO regresyon sonuçlarına göre; yas, $\mathrm{KAH}$ ve nefes darlığı varlı̆̆ı, nötrofil sayısı, üre, CRP, ferritin, Pro-BNP, fibrinojen, IL-6 değerlerinin ciddi seyirli hastalık açısından prediktif göstergeler olduğu saptanmıștır (Sekil 1).

$\mathrm{Bu}$ değișkenler; cok değișkenli logistik regresyon modelinde analize dahil edilmiștir. Elde edilen sonuçlara göre; yas, nefes darlhğı varlığı, üre, ferritin ve Pro-BNP'nin bağımsız prediktif değiskenler olduğu gösterilmiștir (Tablo 3).

Yas, üre, ferritin ve Pro-BNP için yapılan ROC analizi sonuçları Sekil 2'de verilmistir. Bu değiskenler için eșik değerler ("cut-off point"): Yas (59.5), Üre $(33.5 \mathrm{mg} / \mathrm{dL})$, Ferritin $(50.8 \mu \mathrm{g} / \mathrm{L})$ ve Pro-BNP (881 pg/mL) olarak bulunmuștur.

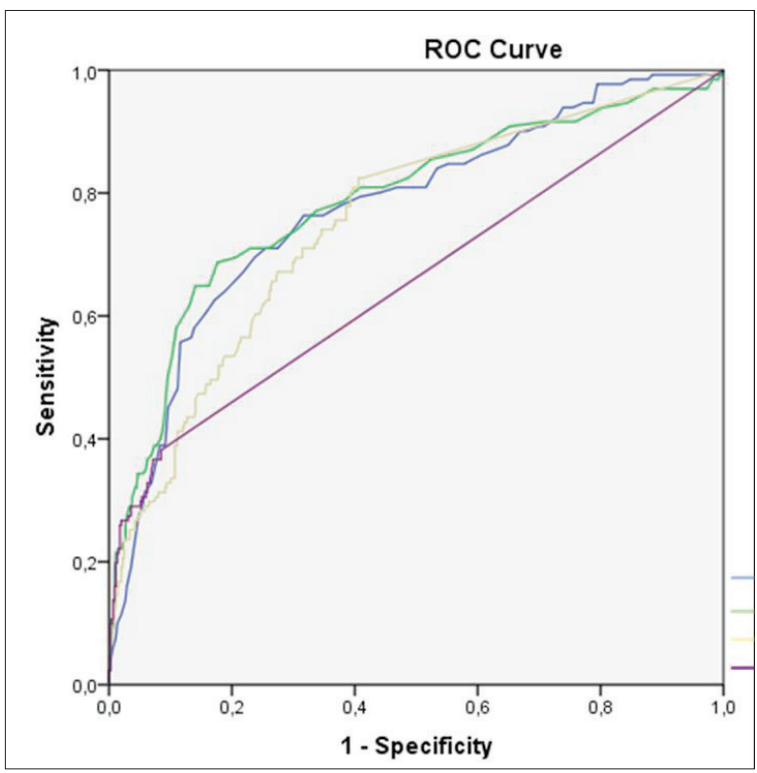

Şekil 2. Yaş, üre, ferritin ve Pro-BNP değerleri ROC analizi sonuçları. 


\section{TARTIŞMA}

Ülkemizde pandeminin erken dönemlerinde Türkiye Sağlık Bakanlığı COVID-19 Tanı ve Tedavi Rehberi'ne uygun olarak; hastaların ciddiyet durumu göz önüne alınmaksızın izolasyon amacıyla tüm PCR pozitif hastalar yatırılmıstır. Bu çalıșma da; böyle bir dönemde üçüncü basamak bir sağlık kurumu olan hastanemizde yatırılarak takip edilen COVID-19 hastaların kapsamaktadır.

Literatürle uyumlu olarak calıșmamıza alınan vakalar coğunlukla orta yas grubu olup erkek olgular büyük coğunluğu olusturmaktadır ${ }^{[9-11]}$. Yine literatürle uyumlu olarak en sik görülen semptomlar öksürük, ates ve nefes darlığıdır $[12,13]$. Hastalarımızın \%22.6'sında ciddi seyirli hastalık gözlenmiș olup fatalite oranı \%8.3 hesaplanmıștır. Ülkemizden benzer dönemde yapılan bașka bir calıșmada ciddi seyirli hastalı oranı \%34.6, fatalite oranını da \%3.2 olarak bildirilmistir ${ }^{14]}$. Yakın zamanda yayınlanan bir meta-analizde tüm dünyada farklı bölgelerde fatalite üzerine risk faktörlerini araștıran 58 makale değerlendirilmiștir. Yatan hastalardaki fatalite oranı \%18.8 (\%0.6-61.5) olarak saptanmıș olup en yüksek oranlar Avrupa (en yüksek İtalya ve İspanya) ve Kuzey Amerika'dan bildirilmistirir ${ }^{[15]}$. Hem hekim hem diğer sağllk personeli sayısı ile hastane ve YBÜ kapasitesi yüksek olan ülkemizde; Cin'deki vakaların görülmesi ardından hizlıca bilim kurulu olusturulmus ve önerileri doğrultusunda nitelikli tanı, tedavi ve ilac temin hizmetleri daha salgının ilk dönemlerinden itibaren sağlanmaya calıșılmıștır ${ }^{[16]}$. Tüm bu faktörlerin ükemizdeki fatalite oranlarının daha düșük olmasında etkili olduğu düșünülmektedir.

COVID-19 fatalite hızı sağlık alt yapısı yanında bazı demografik özelliklere göre de ülkeler arası değisiklik göstermektedir. Bugüne kadar yapilan çalıșmalarda da görüldüğü üzere yaş; ciddi hastalık seyri ve fatalite açısından en önemli demografik özelliklerden biridir ${ }^{14]}$. Genis çaplı bir metaanalizde de 65 yas üstü hastalarda fatalitenin 3.59 kat daha yüksek olduğu görülmüștür ${ }^{[15]}$. Avrupa'da en yüksek fatalite oranlarının bildirildiği ülkelerden olan İtalya'da toplumun dörtte birini 65 yas ve üzeri kișiler olușturmakta olup kaba fatalite hızının \%7.2 bulunduğu bir analizde 80 yas üzeri olgularda fatalite hızının yaklașık \%20'lere cııtığı bildirilmektedir ${ }^{[17]}$.
Nefes darlığ1; ciddi seyir gösteren hastalar1mızın hem önemli bir kısminda (\%54.6) bașvuru sikayeti olarak saptanmıs hem de ciddi seyirli hastalık açısından bağımsız risk faktörü $(\mathrm{OR}=2.4$ [1.4-4.2]) olarak tespit edilmiștir. Benzer sekilde; toplam 1590 hastadan olușan bir kohortta, nefes darlığının hem kritik hastalık hem de fatalite için bağımsız risk faktörü olduğu bulunmustur ${ }^{[18]}$. Cin'de siddetli COVID-19'lu hastalar değerlendirilmis ve bașvuru anında solunum sayısı $>24 / d k$ olanlarda fatalitenin daha yüksek (\%63'e karșllı \%16) olduğu vurgulanmıstır ${ }^{[9]}$. İngiltere'den yapılan bir calıșmada hastaların takiplerinde, 14 gün içinde ölen hastalarda nefes darlığının olması sıklık olarak istatistiksel açıdan anlamlı $(p=0.013)$ tek semptom olarak kaydedilmistir ${ }^{[19]}$. $\mathrm{Bu}$ nedenlerle COVID-19 hastalarının hem bașvuru anında hem de izleminde pulmoner semptomların yakından takibi önem arz etmektedir.

COVID-19'lu hastalarda klinik seyir, eslik eden komorbiditelere bağlı olarak da daha ağır seyredebilmektedir. Hem yurt içi hem de yurt dıș1 verilerle uyumlu olarak vakalarımızda en sık saptanan komorbiditeler HT, DM ve KAH'dır ${ }^{[14,15]}$. LASSO regresyon analizi sonuclarında ise $\mathrm{KAH}$ ciddi hastalık için risk faktörü olarak belirlenmiștir. İspanya'da pandemi bașlangıcında, ulusal sürveyans sistemi kullanılarak yapılan geniş sayılı bir veride fatalite oranı \%11.9 saptanırken; ileri yas (>80 yaș), kronik böbrek hastalığı ve çalıșmamızla uyumlu olarak kardiyovasküler hastalık (KVH) ciddi hastalık ile ilișkili olarak bildirilmiștir ${ }^{[11]}$. Cin'de ülke capında yapilan bir analize göre de $\mathrm{KAH}$ fataliteyi 4.2 kat arttırmaktadır $^{[18]}$. Bir derlemede ise fatalitenin HT varlığında 2 kat (RR: 2.08, \%95 GA: 1.79-2.43), DM varlığında 1.8 kat (RR: 1.87, GA: \%95 1.23-2.84) ve $\mathrm{KVH}$ varlı̆̆ında ise 2.5 kat (RR: 2.51 GA: \%95 1.20-5.26) arttığı raporlanmıștır ${ }^{[15]}$.

Hastaların hastaneye bașvuru anındaki klinik özellik ve komorbiditeleri yanında bazı laboratuvar parametreleri de hastalık ciddiyetinin değerlendirilmesinde yardımcı olmaktadır. Hastalığın ilk görüldüğu yer olan Wuhan'dan yapılan bir calıșmada; hastanede yatan hastaların fatalitesini öngörmek için iki farklı modelleme kullanılmıstır. Klinik modellemede; ileri yas, HT ve $\mathrm{KAH}$ olması risk faktörü olarak saptanırken (sensivite \%92, spesi- 
fite \%77) laboratuvar verilerinin modellemesinde; h-CRP, periferal kapiller oksijen saturasyonu, nötrofil/lenfosit oranı, D-dimer, AST, GFR değerleri risk faktörleri olarak saptanmıștır (sensivite \%100, spesifite \%92). Laboratuvar verileri kullanilarak olușturulan modelleme, klinik modellemeden fataliteyi öngörmede istatistiksel olarak daha anlaml saptanmiștır $(p=0.0157)^{[20]}$. Velavan ve arkadașları tarafından; hafif ve siddetli COVID-19 hastaları için laboratuvar belirteçleri karșılaștırılmıș ve lenfosit sayisı, CRP, d-dimer, ferritin, kardiyak troponin ve IL-6 serum seviyelerinin prognozda önemli olduğu vurgulanmıstır ${ }^{[21]}$. Fransa'dan yap1lan bir calıșmada ise ciddi seyirli hastalık ile ilișkili faktörler arasında; erkek cinsiyet, ileri yas, nefes darlığı ve vücut kitle indeksinin 25-29.9 arasında olmasının yanında CRP yüksekliği, nötrofil hakimiyeti ve lenfopeni gibi laboratuvar parametreleri de bildirilmiștir ${ }^{[10]}$. Bizim çalısmamızda da laboratuvar değerlerinden üre, ferritin ve Pro-BNP değerleri ciddi hastalık için bağımsız risk faktörleri olarak saptanmıștır.

COVID-19'un mevcut kardiyovasküler hastalığı siddetlendirebileceği veya var olan risk faktörlerini artırarak kardiyovasküler komplikasyonlara yol açabileceğini gösteren calıșmalar bulunmaktadır ${ }^{[22,23]}$. Özellikle akut kardiyak hasar ve pihtılașma biyobelirteçlerinin normalden yüksek değerlerde olmasının daha kötui prognozla ilișkisi olduğu bilinmekte$\operatorname{dir}^{[24-27]}$. Bu belirteclerden kardiyak troponin, D-dimer, ferritin, fibrinojen COVID-19 prognozu izle tahmin etmede sıklıkla kullanılırken; Pro-BNP'nin de COVID-19'un prognozunda ilișkili olduğu dikkat cekmektedir ${ }^{[28]}$. Guo ve arkadaşları, taburcu edilen hastalardaki düsük ve stabil serum Pro-BNP düzeylerinin tersine, kritik COVID-19 hastalarında Pro-BNP düzeylerinin giderek arttığını bildirmişlerdir ${ }^{[29]}$. Ayrıca Shi ve arkadașları miyokardiyal hasarı olan COVID-19 hastalarında Pro-BNP düzeylerinin, olmayanlara kıyasla (1689 pg mL'ye karș1 139 pg/mL, p< 0.001) önemli ölçüde arttığını, bu hastalardaki fatalite oranının da oldukça yüksek olduğunu (\%51.2) göstermișlerdir ${ }^{[30]}$. Bizim çalıșmamızda da cok değișkenli logistik regresyon modelinde Pro-BNP bağımsız prediktif değișken olarak gösterilmiș ve belirlenen eșik değerin üzerindeki (881 pg/mL) vakaların önemli bir oranında ciddi seyirli hastalık görülmüștür.
Tüm bunların yanında; ciddi seyirli hastalık ve fatalite için çeșitli çalıșmalarda saptanmıș olan risk faktörleri bir araya getirilerek bazı skorlama sistemleri olușturulmuștur. Amerika'da yap1lan bir calıșmada; hızlı COVID-19 siddet indeksi (qCSI; nazal kanül akıș hızı, solunum hızı ve oksijen saturasyonu ve Brescia-COVID solunum șiddeti ölçeği (BCRSS; hastanın istirahat halinde veya minimal eforda tam cümle ile konușamamas1/hirilt1l solumas1, solunum hiz1 $>22 / \mathrm{dk}$, $\mathrm{SpO}_{2}<\%$ ve akciğer grafisinde bilateral ya da yaygın tutulum olması kıyaslanmıs olup hastalığın ciddiyetini öngörmede qCSI sisteminin daha iyi olduğu saptanmıștır. Ek olarak klinisyenler tarafından daha cok tercih edilen bir skorlama sistemi olan CURB-65 (konfüzyon, üre >42.8 $\mathrm{mg} / \mathrm{dL}$ solunum hizı $\geq 30 / \mathrm{dk}$, sistolik kan basınc1 $<90 \mathrm{~mm} / \mathrm{Hg}$ veya diastolik kan basınc1 $\leq 60$ mmHg, yaș $\geq 65$ ) skorlama sistemi kullanıldığında ise; eșik değer $\geq 3$ olduğu zaman hastalığın ciddiyetini öngörmede iki skorlama sisteminden de daha yüksek sensivite ve spesifiteye (\%71, \%73) sahip olduğu görülmüștür ${ }^{[31]}$.

Calıșmanın hem tek merkezli olması hem de pandeminin sadece erken dönemi vakalarını kapsaması makalemizin kısıtlayıcı yanlarını oluşturmaktadır. Bunun yanında o dönemde; tüm PCR pozitif ve/veya klinik ve radyolojik uyumlu COVID-19 hastalarının yatırılarak izlenmesinden dolayı ciddi hastalık ilișkili risk faktörleri oldukça heterojen bir çalıșma popülasyonunda analiz edilebilmiștir.

Sonuc olarak bu calıșmada; yaș, komorbidite gibi demografik özellikler ile üre, ferritin ve ProBNP gibi bazı laboratuvar değerlerinin COVID-19 hastalığında ciddi hastalık seyri açısından bağımsız risk faktörleri olduğu görülmüștür. Bu faktörlerin dikkate alınarak riskin öngörülmesi hekim ve diğer sağlık çalısanlarına yakın takip, erken ve uygun tedavi ile fatalitenin düșürülmesi ve sürecin uygun yönetimi açısından yol gösterici olacaktır. Bunun yanında hastane yatak veya mali kapasite açısından sınırlı kaynakları olan ülkelerde, düșük risk öngörülen kișilerde gereksiz yere uzun süre hastaneye yatıșlarını önleyerek, hastane yataklarının optimum kullanımı için de yardımcı olacaktır. 


\section{TEȘEKKÜR}

Pandemi süresince gece gündüz yılmadan, özveri ile calısarak sürece büyük destek veren; öncelikle kendi hastanemizin calıșanları olmak üzere, tüm sağlık calıșanlarına teșekkürü bir borç biliriz.

\section{ETIK KURUL ONAYI}

Calıșma için Sağlık Bilimleri Üniversitesi Girișimsel Olmayan Araștırmalar Etik Kurulundan onay alındı (Tarih: 14.05.2020, Karar No: 2020176).

\section{ÇIKAR ÇATIȘMASI}

Yazarlar bu makale ile ilgili herhangi bir cıkar çatıșması bildirmemișlerdir.

\section{YAZAR KATKISI}

Anafikir/Planlama: MF, GY

Analiz/Yorum: MF, GY

Veri sağlama: MF, SK, EK

Yazım: MF, GY

Gözden Geçirme ve Düzeltme: MF, GY, GF, ÜS, YC

Onaylama: Tüm yazarlar

\section{KAYNAKLAR}

1. Zhu N, Zhang D, Wang W, Li X, Yang B, Song J, et al. A Novel Coronavirus from patients with pneumonia in China, 2019. N Engl J Med 2020;382(8):727-33.

2. World Health Organization (WHO). WHO Director-General's opening remarks at the media briefing on COVID-19. Available from: https://www.who.int/director-general/speeches/detail/who-director-general-s-opening-remarks-atthe-media-briefing-on-covid-19---11-march-2020.

3. Worldometer. COVID-19 Coronavirus Pandemic. USA: Dadax. Available from: https://www.worldometers.info/coronavirus/?\%3D\%3D (Accessed date: 20 January 21).

4. Sağlık Bakanlığı. COVID-19 Bilgilendirme Sayfası (Türkiye'deki Güncel Durum) [internet]. Ankara: Sağılı Bakanlığı. Available from: https://covid19.saglik.gov.tr/ (Accessed date: 20 January 21).

5. European Centre for Disease Prevention and Control (ECDC). Transmission of COVID-19. Available from: https://www.ecdc.europa.eu/en/covid-19/latest-evidence/ transmission

6. Huang C, Wang Y, Li X, Ren L, Zhao J, Hu Y, et al. Clinical features of patients infected with 2019 novel coronavirus in Wuhan, China. The Lancet 2020;395(10223):497-506.

7. Guan WJ, Ni ZY, Hu Y, Liang WH, Ou CQ, He JX, et al. Clinical Characteristics of Coronavirus Disease 2019 in China. N Engl J Med 2020;382(18):1 708-20.
8. World Health Organization (WHO). Clinical management of COVID-19. Available from: https://www.who.int/publications/i/item/clinical-management-of-covid-19

9. Zhou F, Yu T, Du R, Fan G, Liu Y, Liu Z, et al. Clinical course and risk factors for mortality of adult inpatients with COVID-19 in Wuhan, China: a retrospective cohort study. Lancet 2020;395(10229):1054-62.

10. Kaeuffer C, Le Hyaric C, Fabacher T, Mootien J, Dervieux B, Ruch $Y$, et al. Clinical characteristics and risk factors associated with severe COVID-19: prospective analysis of 1,045 hospitalised cases in North-Eastern France, March 2020.

11. Working group for the surveillance and control of COVID-19 in Spain. The first wave of the COVID-19 pandemic in Spain: characterisation of cases and risk factors for severe outcomes, as at 27 April 2020. Euro Surveill 2020;25(50).

12. Docherty $A B$, Harrison $E M$, Green $C A$, Hardwick $H E$, Pius $R$, Norman L, et al. Features of 20133 UK patients in hospital with COVID-19 using the ISARIC WHO Clinical Characterisation Protocol: prospective observational cohort study. BMJ 2020;369:m1985.

13. Cummings MJ, Baldwin MR, Abrams D, Jacobson SD, Meyer BJ, Balough EM, et al. Epidemiology, clinical course, and outcomes of critically ill adults with COVID-19 in New York City: a prospective cohort study. The Lancet 2020;395(10239):1763-70.

14. Karakoc ZC, Pinarbasi Simsek B, Asil R, Dodurgali R, Caliskaner F, Ozsari A, et al. First Wave in COVID-19 Pandemic: a single center experience. Klimik Dergisi/Klimik Journal 2020;33(3):223-9.

15. Noor FM, Islam MM. Prevalence and associated risk factors of mortality among COVID-19 patients: a meta-analysis. I Community Health 2020;45(6):1270-82.

16. Eraksoy H. COVID-19 Pandemic: leaving first four months behind. Klimik Dergisi/Klimik Journal. 2020;33(1):1.

17. Livingston E, Bucher K. Coronavirus Disease 2019 (COVID-19) in Italy. JAMA 2020;323(14):1335.

18. Chen $R$, Liang W, Jiang $M$, Guan W, Zhan C, Wang $T$, et al. Risk factors of fatal outcome in hospitalized subjects with Coronavirus Disease 2019 From a nationwide analysis in China. Chest 2020;158(1):97-105.

19. Tomlins J, Hamilton F, Gunning S, Sheehy C, Moran E, MacGowan A. Clinical features of 95 sequential hospitalised patients with novel coronavirus 2019 disease (COVID-19), the first UK cohort. I Infect 2020;81(2):e59-e61.

20. Wang K, Zuo P, Liu Y, Zhang M, Zhao X, Xie S, et al. Clinical and laboratory predictors of in-hospital mortality in patients with Coronavirus Disease-2019: a cohort study in Wuhan, China. Clin Infect Dis 2020 Nov 19;71(16):2079-2088.

21. Velavan TP, Meyer CG. Mild versus severe COVID-19: Laboratory markers. Int J Infect Dis 2020;95:304-7.

22. Samidurai A, Das A. Cardiovascular Complications Associated with COVID-19 and Potential Therapeutic Strategies. Int J Mol Sci 2020;21(18). 
23. Long B, Brady WJ, Koyfman A, Gottlieb M. Cardiovascular complications in COVID-19. Am / Emerg Med 2020;38(7):1504-7.

24. Pourbagheri-Sigaroodi A, Bashash D, Fateh F, Abolghasemi $H$. Laboratory findings in COVID-19 diagnosis and prognosis. Clin Chim Acta 2020;510:475-82.

25. Rod JE, Oviedo-Trespalacios O, Cortes-Ramirez J. A brief-review of the risk factors for covid-19 severity. Rev Saude Publica 2020;54:60.

26. Zheng Z, Peng F, Xu B, Zhao J, Liu H, Peng J, et al. Risk factors of critical \& mortal COVID-19 cases: A systematic literature review and meta-analysis. J Infect 2020;81(2):e16-e25.

27. Chidambaram V, Tun NL, Haque WZ, Majella MG, Sivakumar RK, Kumar A, et al. Factors associated with disease severity and mortality among patients with $\mathrm{CO}$ VID-19: A systematic review and meta-analysis. PLoS One 2020;15(11):e0241541.

28. Aboughdir M, Kirwin T, Abdul Khader A, Wang B. Prognostic value of cardiovascular biomarkers in COVID-19: a review. Viruses 2020;12(5).

29. Guo T, Fan Y, Chen M, Wu X, Zhang L, He T, et al. Cardiovascular Implications of fatal outcomes of patients with Coronavirus Disease 2019 (COVID-19). JAMA Cardiol 2020;5(7):811-8.
30. Shi S, Qin M, Shen B, Cai Y, Liu T, Yang F, et al. Association of cardiac injury with mortality in hospitalized patients with COVID-19 in Wuhan, China. JAMA Cardiol 2020;5(7):802-10.

31. Rodriguez-Nava G, Yanez-Bello MA, Trelles-Garcia DP, Chung CW, Friedman HJ, Hines DW. Performance of the quick COVID-19 severity index and the Brescia-COVID respiratory severity scale in hospitalized patients with $\mathrm{CO}$ VID-19 in a community hospital setting. Int I Infect Dis 2021;102:571-6.

\section{Yazıșma Adresi/Address for Correspondence}

Dr. Mine FiLiz

Sağlık Bilimleri Üniversitesi,

Gülhane Eğitim ve Araștırma Hastanesi,

İnfeksiyon Hastalıkları ve Klinik Mikrobiyoloji Kliniği, Ankara-Türkiye

E-posta: minehasirci@hotmail.com 